Vol 41 (2016) No 184 1-26

\title{
Privatization and Accountability Trends and Policies in U.S. Public Higher Education *
}

\author{
James C. Hearn ${ }^{1}$, Jarrett B. Warshaw ${ }^{2}$, Erin B. Ciarimboli ${ }^{3}$
}

\begin{abstract}
National tertiary-education systems are in a period of transition worldwide. Numerous systems have grown dramatically in enrollments and many have undergone structural reforms. Often, these organizational changes flow in the direction of greater privatization in association with increased accountability for performance on various dimensions. This essay outlines the growing movement in that direction in the U.S. and examines the trends' implications for management, enrollment, stratification, pay, and staffing in that country. Conclusions focus on broader questions of the public good.
\end{abstract}

Keywords

Tertiary education

Privatization

Accountability

Reform

Markets

Article Info

Received: 04.02.2016

Accepted: 03.04.2016

Online Published: 27.04.2016

DOI: 10.15390/EB.2016.6270

\section{Introduction}

National tertiary-education systems are in a period of transition worldwide. Numerous systems have grown dramatically in enrollments, and many have undergone structural reforms. Across countries, the most visible recent structural change has been movement toward a unified European system of higher education, but parallel efforts are taking place in regions worldwide. Within countries, many nations from China to India to Brazil to Mexico have begun focusing on developing "world-class universities" (e.g., Altbach \& Balán, 2007; Rhoads, Wang, Shi, \& Chang, 2014). Driven by international "league tables" and rankings, numerous nations have begun aggressively pursuing the core indicators of global stature: increased funding for scientific research, publications in top international journals, and the production and hiring of PhDs. To finance these initiatives, many countries and, in turn, their institutions of higher learning, are demonstrating increased openness to "cost sharing" via lowering state subsidies, initiating and raising tuition charges, and implementing student loan programs (Johnstone \& Marcucci, 2010). At the same time, some national governments, such as Japan, have begun pushing harder than ever to control and reward quality in institutions' educational offerings and research activity (Grove, 2015).

\footnotetext{
* This work was supported by the Institute of Higher Education at the University of Georgia.

${ }^{1}$ University of Georgia, Institute of Higher Education, USA, jhearn@uga.edu

${ }^{2}$ University of Georgia, Institute of Higher Education, USA, jwarshaw@uga.edu

${ }^{3}$ University of Georgia, Institute of Higher Education, USA, ebciar@uga.edu
} 
These developments worldwide are uneven: some countries continue to resist the trends. Still, there is no question that institutions and systems are increasingly being asked to perform as economic engines and to treat students less as nascent citizens contributing to national interests and more as paying consumers to be pleased. We characterize these global trends as privatization and accountability.

In this article, we assay the emergence of these two developments and review the research on them. We consider only available data and available theoretical and analytic literature, and we undertake no new empirical analyses, but our goal is to examine systematically the developments and their implications, with particular attention to developments in the U.S. Arguably, the U.S. is further "out on the curve" in these movements than most other nations, and may thus provide helpful evidence regarding the risks and rewards of the growing emphases on privatization and accountability.

Of course, terminology can always be debated so, as a first step, it is important to clarify terms. We use the term privatization broadly to refer to:

- the increasing framing of institutional and system goals in economic terms;

- the growing prioritization of student, service, and labor markets;

- the parallel transfer of formerly governmental authority and decision-making to markets; and

- the corporatization of institutional finance in the direction of cost-sensitive pricing, contingent faculty hiring, responsibility-centered budgeting, and revenue-centered structural innovation. ${ }^{1}$

By accountability, we refer to the increased reliance on regulated autonomy rather than on centralized diktat. In using the adjective "regulated," we refer to the structural cost of the new autonomy: rather than truly freeing institutions of central controls, current trends tend simply to periodicize those controls. That is, while day-to-day decisionmaking may be less tightly vested in higher levels organizationally, new bureaucratic regimes (for example "quality councils") can arise requiring expanded monitoring of enrollments, revenues, and costs, as well as new monthly or annual reporting requirements. Along with those new regimes may come sanctioning of performance, through shifted governmental support tied to institutions' success on chosen metrics.

Using a framing analogous to that which we have described, Rizvi (2006) notes the ubiquity of this movement worldwide, arguing that over recent decades,

... the ideology of privatization has been embraced by most higher education systems around the world... Public institutions in most parts of the world have been encouraged, if not compelled, to adopt the principles of market dynamics in the management of their key functions. (p. 65)

\footnotetext{
${ }^{1}$ Some would define privatization more narrowly than we do in this essay, focusing on specific linkages between systems, private corporations, and individual actors, via "outsourcing," cooperative agreements, and the like.
} 
Numerous other authors make the same point. Schugurensky (1999) has observed that, "what is most striking about the current higher education restructuring is the unprecedented scope and depth of changes taking place as well as the similarity of changes occurring in a wide variety of nations having different social, political, historical, and economic characteristics" (p. 82). Similarly, Bozeman (2007) notes:

Since its inception, the United States has provided fertile ground for market-based philosophies of human behavior and public policy. However, in recent times, market values have been elevated to a normative level perhaps unsurpassed ... Even the bastions of social and public values - Western European nations - have increasingly come to grips with market values, especially in the face of increasing financial burdens on the welfare state. Few outposts remain where policymakers confidently reject economic efficiency and growth as transcendent goals of public policy and its management. (p. 3)

Several factors have driven the worldwide growth in privatization and accountability pressures in recent years, but three seem especially noteworthy. First, slowdowns and disruptions in worldwide economic growth have generated governmental pressures on institutions to connect their activities more closely to economic development and growth. Facing crises internally and abroad, major changes in markets for commodities and technology, and constrained budgets, national governments have often turned to tertiary institutions to produce more graduates in valued fields and to develop usable knowledge and technology. In concert, governments have sometimes cut funding for institutions and programs in more controversial fields, particularly those offering questionable national returns. Increasingly, governments are asking institutions to justify national support on explicit criteria rooted in anticipated economic payoffs.

Second, nations are growing ever more aware of the interconnectedness of educational and economic systems, and to the cross-border movement of capital, ideas, labor, and students (Marginson, 2000, 2012). In recent years, waves of refugees and migrant laborers provide visible evidence of the declining strength of political and economic borders, but there is ample evidence of the growing permeability of educational and knowledge borders as well. While nations vary dramatically in their openness to enrolling students from abroad, no nation is immune to technological change fueled by knowledge development. Indeed, inattention to this shifting landscape creates economic, social, and even military vulnerabilities. This growing anxiety fuels the turn to higher education institutions, as governments seek greater knowledge transmission via enrollments and knowledge development via research. Governments increasingly expect institutions to connect their nations effectively and efficiently with the worldwide flow of people, resources, and ideas, and to be incentivized, evaluated, and sanctioned on that basis. In effect, governments may impose a tax on students, faculty, fields, and institutions not directly and measurably protecting and enhancing a nation's place in world economic and social systems.

Third, dating to the prominent 1980s leadership of Reagan, Thatcher, and others, there has been worldwide ascendance in ideologies favoring the employment of private capital, corporate innovation, loose regulation, and freer, more adaptive labor markets enabling the achievement of national goals. Harvey (2005) suggests that these ideologies have been codified as "neoliberalism," a "theory of political economic practices that proposes that human well-being can best be advanced by liberating individual entrepreneurial freedoms and skills within an institutional framework characterized by strong private property rights, free markets, and free trade" (p. 2). Numerous analysts have observed that higher education has been deeply incorporated into this ideological shift (e.g., see Pusser, 2008; Slaughter \& Rhoades, 2004). Whether one terms this movement "neoliberalism," "marketization," or something else, and whether one accepts the notion that consistent philosophical stances are driving national attitudes and policies toward the role of tertiary systems, there is little question that an identifiable set of ideas has risen in parallel with the ascendance of privatization and accountability in the sector. 
This surge toward increased privatization and accountability has been based on an emerging logic concerning the role of tertiary education in national success. This logic maintains that national goals are best served by loosening direct governmental control while simultaneously tying governments' educational allocations more closely to performance. That is, governments are providing institutions greater discretion to build relationships with corporations and other private actors and incentivizing them to innovate in the pursuit of revenue-generating enrollments and research and service contracts. At the same time, governments are demanding measurable returns on their investments, as increased autonomy comes with the price of increased vulnerability for poor performance. This "bargain" confounds any attempt to characterize the trends as simply centralization or decentralization: controls over the targets of centralized allocations are lessened, but valued outcomes that were formerly only loosely inspected are subject to increased governmental scrutiny.

It is not difficult to see both benefits and risks of this approach. Few institutions will deny the attractiveness of having greater discretion over day-to-day choices as well as longer-term strategic decision-making. Indeed, organizational analysts have long valued university autonomy as conducive to improved knowledge development and transmission (e.g., see Clark, 1998). However, institutions' retreat from essentially a secure "governmental agency" niche into a more market-driven and risky role can be stressful (Brewer \& Tierney, 2011). What is more, privatization and heightened accountability can reward practical or applied research and instruction over basic inquiry and teaching, encourage focus on short-term rather than longer term outcomes, and privilege wellresourced students over academically vulnerable and often socioeconomically disadvantaged students.

Below, we consider these issues in the context of recent developments in the U.S., arguably one of the nations on the frontier of the worldwide movement toward privatization and accountability (McLendon \& Hearn, 2009). As Dill (1997) has observed, "Long perceived as a unique characteristic of the U.S. system ..., experiments with market competition in academic labor markets, institutional finance, student support, and the allocation of research funds are now evident in the higher education policy of many different nations" (p. 167). This attention to the private side of public tertiary education is now worldwide, and the possibilities and the risks being revealed in the U.S. may be increasingly of interest to governmental and educational leaders worldwide.

\section{Privatization and Accountability Trends in the U.S.}

The United States unquestionably has a national tertiary education system, but it differs appreciably from most other systems around the world. By comparison internationally, U.S. higher education lies toward the lowest end on any continuum of formalized national centralization. The national (federal) government influences public colleges and universities through funding mechanisms, regulations, and laws, but does not coordinate a formal system through an education ministry (Ben-David, 1992). Historically, the 50 U.S. states have held primary responsibility for steering and funding institutions. In practice, however, the states often defer to one or several lay boards that can govern sectors (e.g., four-year institutions and/or two-year institutions), segments (e.g., research universities, comprehensive universities, community colleges, etc.), or individual campuses (McGuinness, 2011). Governance structures vary widely by state and, as such, also reflect differing degrees of formal state authority over public institutions. Analogous to private, non-profit colleges and universities, whose "charters" grant them independence from direct governmental involvement, those in the public sector can claim institutionalized or even constitutional autonomy buffering them from potentially "meddlesome" politicians (McLendon \& Hearn, 2009). In this way, the U.S. system has relied more on competitive markets for students, faculty, and funding than on national or subnational governments to steer higher education (Clark, 1983). 
To emphasize the predominant role of market forces in U.S. higher education may mask the evolving authority relations between public colleges and universities and government. In the 1970s, the federal government shifted the allocation of financial aid from institutions to students. Such a move was intended to lead toward efficiencies in higher education, as institutions were incentivized to compete for students who, as consumers, used their financial aid to purchase enrollment in a marketplace. Today, national efforts now increasingly focus on measuring and rating institutions in order to shape students' decisions about where to enroll. Since the 1980s, many states have decentralized governance of tertiary education and devolved decision-making authority to the campus level. Others have increased centralization, leading toward active governing boards (Bastedo, 2005), but, on the whole, most states have willingly redistributed substantive and procedural autonomy (Berdahl, 1998). For example, numerous public colleges and universities have gained control over tuition pricing, academic program review, personnel policies, and daily operations (the "how," or procedural matters of higher education), while ceding some influence to states over mission differentiation and goals (the "what," or substantive nature of higher education). Paradoxically, as some public colleges and universities seek the highest levels of autonomy, they may also deepen their entwinement with states through heightened accountability to deliver on their performance goals to serve the public good (Leslie \& Berdahl, 2008; Pusser, 2008). Thus, government-both federal and state - can and often does shape the constraints in which public colleges and universities maneuver to compete in markets for faculty, students, and funding.

Without doubt, shifts in the financing of U.S. public higher education add complexity to newly emerging authority relationships. Federal and state policy choices that favor private, nongovernmental sources of funding to public colleges and universities tend to overlap with heightened emphases on decentralization, granting some latitude to institutions to adapt in order to compete for other streams of revenue. For example, facing decreased core allocations from the state, institutions might choose to pursue increased tuition revenues, and might also choose to pursue expanded funding from other sources, such as research grants and service contracts. Such latitude, as we address in this paper, carries implications for students, whose tuition and fees may become a primary funding mechanism. Yet it also shapes institutional approaches to faculty recruitment and composition, as well as pursuits of profits from markets for research. Still, these overall patterns in public funding come with increasing scrutiny of higher education performance and thus accountability. Next, we address federal trends in this arena, followed by state-level developments.

The federal government funds few institutions directly via broad-based appropriations (exceptions include military academies and campuses with specialized missions, such as Historically Black Colleges and Universities, Hispanic Serving Institutions, and Tribal Colleges). By far, the greatest proportion of the U.S. federal government's funding for higher education comes via support for research and student financial aid. To leverage higher education for knowledge production, the federal government funds research and development (R\&D), allocating about \$29 billion (in 2014 constant dollars) per year to colleges and universities in the U.S. ${ }^{2}$ The bulk of this money flows to "mission agencies" that administer grants and contracts, including the prominent National Science Foundation, National Institutes of Health, Department of Defense, and Department of Energy. As national needs and interests shift, federal R\&D funding fluctuates across these agencies (Slaughter \& Rhoades, 1996). What is more, priorities for funding within the agencies themselves may also change, influencing the incentives facing institutions (Warshaw, 2015). Competition for federal R\&D funding often constitutes a "tournament," with success providing critical resources to fund scientists and their research, as well as concomitant increases in institutional prestige (Stephan, 2012). These resources tend to be concentrated among only a select group of elite universities (Geiger, 2004). While many institutions may seek to emulate the elite in order to increase their chances of securing these resources,

\footnotetext{
${ }^{2} \$ 29$ billion reflects median federal R\&D funding to U.S. colleges and universities over consecutive years from 1980 to 2014, adjusted for inflation using the Higher Education Price Index (HEPI) and reported in 2014 constant dollars.
} 
the likelihood of capturing federal R\&D funding among the aspirational competitors remains relatively low (Brewer \& Tierney, 2011).

In addition to funding research, the federal government allocates substantial funding for student financial assistance. The Pell Grant program, which began in 1973, provides need-based assistance to students. Students from virtually all low-income families qualify, as do many students from middle-income backgrounds, depending on the costs of the colleges they attend. When students who qualify for Pell Grants enroll in college, their institutions receive the funding allotments to then distribute to them. Over the years, total expenditures for the program have ranged from $\$ 16.5$ billion in 2004-05 to $\$ 39$ billion in 2010-11 to an estimated \$30.3 billion in 2014-15, in constant 2014 dollars (College Board, 2015b). These recent funding levels typically exceed the federal outlays to colleges and universities for R\&D purposes, but their "purchasing power" has often been a point of critique among researchers and analysts (e.g., St. John \& Wooden, 2006). For instance, students who enroll in college full-time and qualify for the Pell Grant may receive a maximum award of \$5,645 (in 2013-14), but the program's coverage has declined for individual students relative to college costs. In 2005-06, the maximum grant covered $74 \%$ of average tuition and fees at four-year public institutions, but by 201516 the maximum award met only about $61 \%$ of average tuition and fees at such institutions (College Board, 2015b). To be sure, the federal government offers other forms of grant aid, through its workstudy program (in which qualifying students receive money while they hold part-time employment on campus) and its tuition benefits to military veterans. Additionally, some families, albeit mostly among the upper socioeconomic classes, may receive educational tax credits or participate in taxadvantaged savings plans. But the predominant focus of today's federal student aid centers on loans.

As funding for the Pell Grant program weakened relative to the growth of college tuition, fees, and living expenses, federally-backed loans have become an increasingly critical factor in the ways students and families finance college. In the 1980s, amid national movements toward deregulation, privatization, and market competition, the federal government leveraged its Federal Family Education Loans (FFELP) to subsidize private lenders to loan money to students for college. To protect these lenders from defaults on loans, the government allocated additional taxpayer money to "bail-out" these companies (Mettler, 2011). By the late 1990s, the program had been renamed Stafford Loans, and private capital for college rose to nearly \$38 billion in 2001-2002 (St. John \& Wooden, 2006).

In the same period, the federal government initiated its second largest program for guaranteeing private capital market loans for families of undergraduate students, Parent Loans for Undergraduate Students (PLUS). These PLUS loans totaled about $\$ 6.4$ billion in 2002-03 and reached $\$ 10.6$ billion in 2014-15, in 2014 constant dollars (College Board, 2015b). While the federal government does provide federal capital in revolving accounts for college and university campuses to administer (as part of the Perkins Loan program), national policy has primarily encouraged students and families to draw on private rather than federal sources for loans. Strikingly, total borrowing of loans through federal programs rose from $\$ 45.2$ billion in 2006-07 to an astounding $\$ 76.6$ billion in 2010-11, before declining to $\$ 61.1$ billion in 2014-15 in 2014 dollars (College Board, 2015b). ${ }^{3}$

\footnotetext{
${ }^{3}$ The large amount borrowed in 2010-11 may be related to after-shocks of the worldwide market collapse in 2008 and subsequent economic malaise. This could be considered, then, an outlier or anomaly, though times of economic constraint may nevertheless bring into sharp focus the underlying orientations that inform policy and practice in less turbulent periods.
} 
The evolving distribution of federal student aid apportioned as grants (public money directly invested in students), loans (including public and private capital directly invested in students), and tax benefits (federal tax credits written-off as deductions for families of students) illustrates the privatization of the federal role in U.S. financial aid policy. Figure 1 shows the changing percentage of federal student aid per full-time equivalent student, by type of program (over consecutive years from 1994-95 to 2014-15). Loans remain the predominant funding mechanism, followed by grants and tax benefits respectively. The sizeable gap between loans and grants seems to attenuate slightly in recent years, but this may be attributed to the sharp rise in grant funding for military veterans. In 2014 constant dollars, outlays for the military veterans' program jumped from \$363 per FTE student in 2008-09 to \$650 per FTE student in 2009-10 to its current level of \$1,012 per FTE student in 2014-15 (College Board, 2015b). The steady climb in tax benefits could bode well for national interests in both participation and attainment, though the policy typically targets high-income families whose students are likely to have attended college anyway (Mettler, 2011).

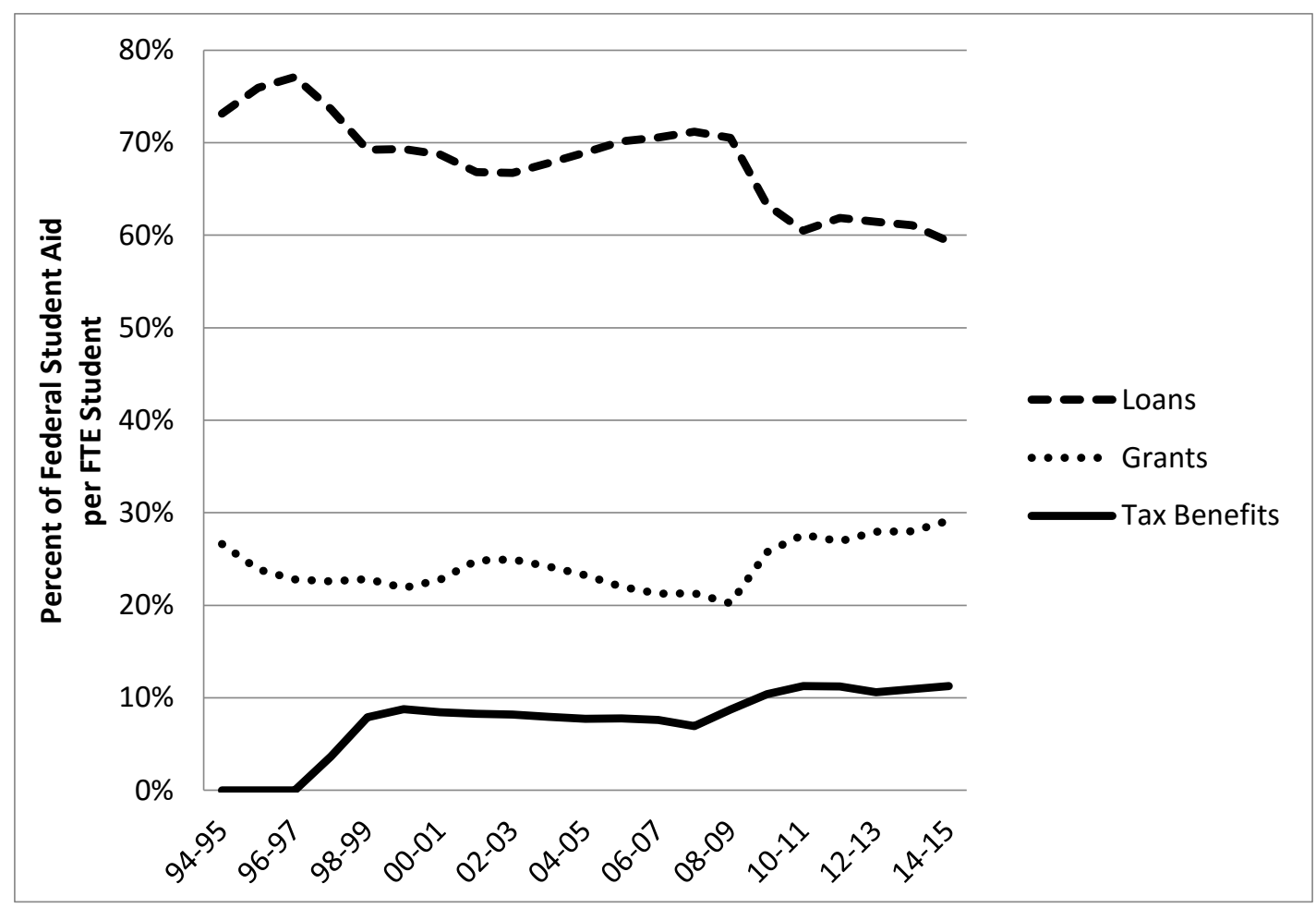

Figure 1. Percent of federal student aid per full-time equivalent student, by type of funding, 1994-95 to 2014-15. Note: The federal student aid programs were grouped as follows: "Loans" consisted of Stafford, PLUS, and Perkins, "Grants" consisted of Pell, Veterans and Military, and Work-Study and Federal Supplemental Education Opportunity Grants (FSEOG), and "Tax Benefits" consisted of Educational Tax Benefits. Source: Calculations derived from data as reported in College Board Trends in Student Aid 2015 (see p. 17, Figure 6).

The federal government directs more funding to students and families than to institutions, but nevertheless has intensified pressures on colleges and universities to demonstrate performance in achieving student success and meeting national needs of developing an educated workforce. Indeed, U.S. President Barack Obama has championed the goal of attaining a $60 \%$ degree-completion rate among tertiary students in the U.S. by 2020. Advocates of this policy goal argue that achieving it would allow the U.S. to strengthen its educational and economic competitiveness relative to other OECD countries (Perna \& Finney, 2014). To be sure, the U.S. may not necessarily meet its ambition in the specified amount of time; OECD comparisons in this arena are largely based on degree completions, an outcome more difficult to achieve than certificates and other forms of certification and 
credentials (Hauptman, 2012). But the national interest in holding colleges and universities accountable for student success has, in this context, become evermore salient.

Attempts at the national-level to assess-and, in effect, grade-colleges and universities are not altogether new. In every other year from 2000 to 2008, the National Center for Public Policy and Higher Education, a non-profit organization, released a report entitled "Measuring Up: The National Report Card on Higher Education." The center rated each of the 50 states, rather than individual institutions, on measures of student preparation, participation, affordability, completion, and benefits. Notoriously, in 2008, 49 states received "failing" grades on affordability (the cost of attending college relative to median family income), and all states received an "incomplete" on student learning due to insufficient data to allow for cross-state comparisons (Lederman, 2010). These outcomes, however, seem more associated with factors over which states have little direct control, such as wealth, education levels, and growth, than with factors they can substantively influence, such as higher education governance structures and accountability systems (Volkwein \& Tandberg, 2008).

In recent years, President Obama has heightened attention toward accountability for higher education. In 2013, he announced plans to rate colleges and universities with the College Scorecard, a means to help students and families make college decisions based on institutional comparisons of measures of access, affordability, and other outcomes, including graduation/transfer rates and graduate earnings (Department of Education, 2013). The Scorecard is indeed now "live" and active, searchable online at https://collegescorecard.ed.gov, though whether it will be effective in increasing enrollments and, ultimately, the national goal of completion, remains less clear.

In contrast to the federal government, the 50 U.S. states provide the largest share of direct governmental appropriations to public colleges and universities. For example, states allocated $\$ 65.6$ billion to higher education in 1984-85 (in 2014 constant dollars) and, 30 years later, expended about $\$ 81$ billion in 2014-15 (College Board, 2015a). However, trends over time suggest some dramatic fluctuations, as higher education is often treated as a "balance wheel" for state budgets (Hovey, 1999). State funding variability is based in several factors. First, unlike other areas of state funding such as primary and secondary education, healthcare, prison systems, and transportation, there are few legal or contractual controls on spending on public tertiary education, and that spending is far less frequently tied to matching requirements from the federal government and other sources. This flexibility is appealing when overall state budgets must be cut. Unlike other arenas of public funding, public tertiary education has the capacity to attract revenue from a variety of non-state sources, such as tuition and fees, federal research grants, research and service contracts, and philanthropic donations. Finally, the demand for public postsecondary education tends to be rather inelastic with respect to price, meaning that tuition rises tend to raise net revenues rather than drive students away. Thus, legislators can cut state tertiary funding, permit tuition increases, and remain confident that institutions will not suffer as dramatically as other sectors facing a similar proportionate cut. For all of these reasons, public higher education institutions tend to experience disproportionate state funding cuts when state economies are suffering. What is more, even when state appropriations seem to increase over a particular set of years, they do not often keep pace with inflation.

To understand the state-funding climate for public institutions more fully, it is helpful to turn to scale-adjusted measures, including state funding per $\$ 1,000$ of personal income and state funding per full-time equivalent (FTE) enrollment. The worldwide market crash of 2008 and subsequent economic recession limited state resources for tertiary education (Zumeta, 2010). Many states have been slow to recover (Dadayan \& Boyd, 2013). It is important to stress, however, that the "Great Recession" simply exacerbated longstanding patterns of decreasing state financial support to tertiary education. The relative share of state budgets apportioned to public colleges and universities was in decline prior to the recession, and there is no sign of that abating as economic conditions improve. State appropriations per $\$ 1,000$ of personal income, an indicator of funding for higher education relative to state wealth, steadily declined from \$9.74 in 1989-90 to \$5.55 in 2014-15, in 2014 constant dollars (College Board, 2015a). 
Analogous to measures of state wealth allocated to tertiary education, state funding per FTE student shows a largely downward trajectory. Figure 2 suggests that direct state support in 2014 constant dollars hit its peak in 1987-88 at $\$ 10,379$ per FTE student and has not approached such heights again. Over this period, the number of FTE students increased from about 6.7 million in 198485 to 10.7 million in 2014-15, and state funding kept pace with neither rising student demand nor increasing institutional costs in providing educational services (Winston, 1999). Together, these trends seem to signal movement from "state-supported" to "state-assisted" universities, and ultimately, to what Duderstadt (2000, p. 312) has termed the era of "state-located" institutions.

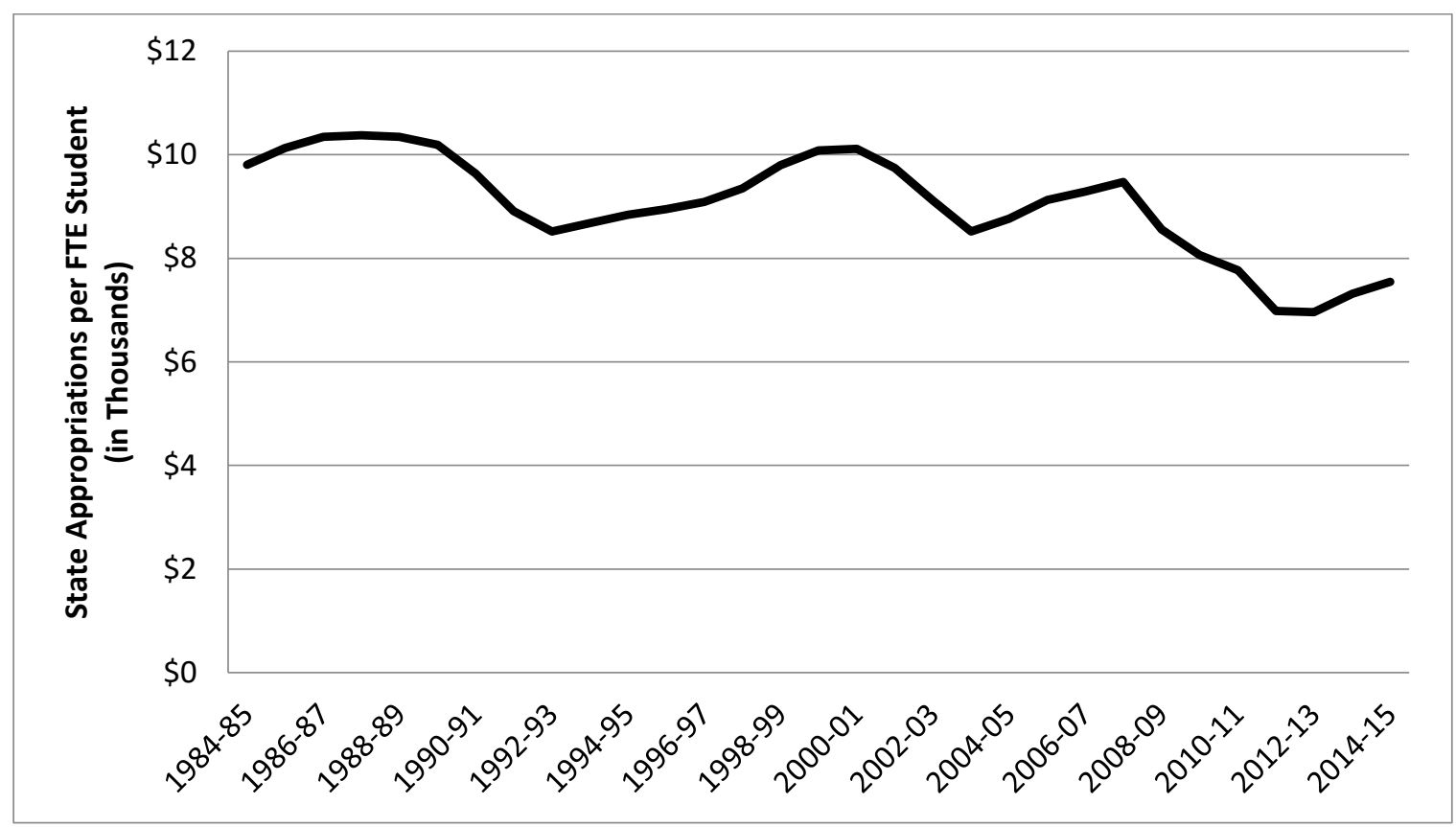

Figure 2. State appropriations per FTE student. Note: Dollars reported in 2014 constant dollars. Source: College Board Trends in College Pricing 2015 (p. 27, Figure 16B).

In light of declines in state funding to public higher education, tuition and fees have increased significantly at public colleges and universities, forcing students to pay a greater proportion of their college expenses. Institutions have "turned to students to increasingly finance their operations, further reinforcing the notion of education as a private, rather than a public, good" (Desrochers \& Hurlburt, 2016, p. 1). Average tuition and fees at four-year universities have more than doubled since 1970, growing from $\$ 9,625$ to $\$ 20,234$ in 2012-13 (in constant dollars), while incomes have remained relatively stagnant (Calahan \& Perna, 2015). This growth in college costs has been especially prominent in public higher education, where average annual tuition and fees for a four-year university have risen to $\$ 9,410$ in 2015-16, an increase of nearly 40\% since 2005-06 (College Board, 2015a). Adding to these costs at four-year schools are on-campus living requirements, which carry considerable room and board charges that can more than double the cost of attendance (College Board, 2015a). Below, Figure 3 charts these growing tuition and fees, costs including room and board, and net costs over time within the public four-year sector. 


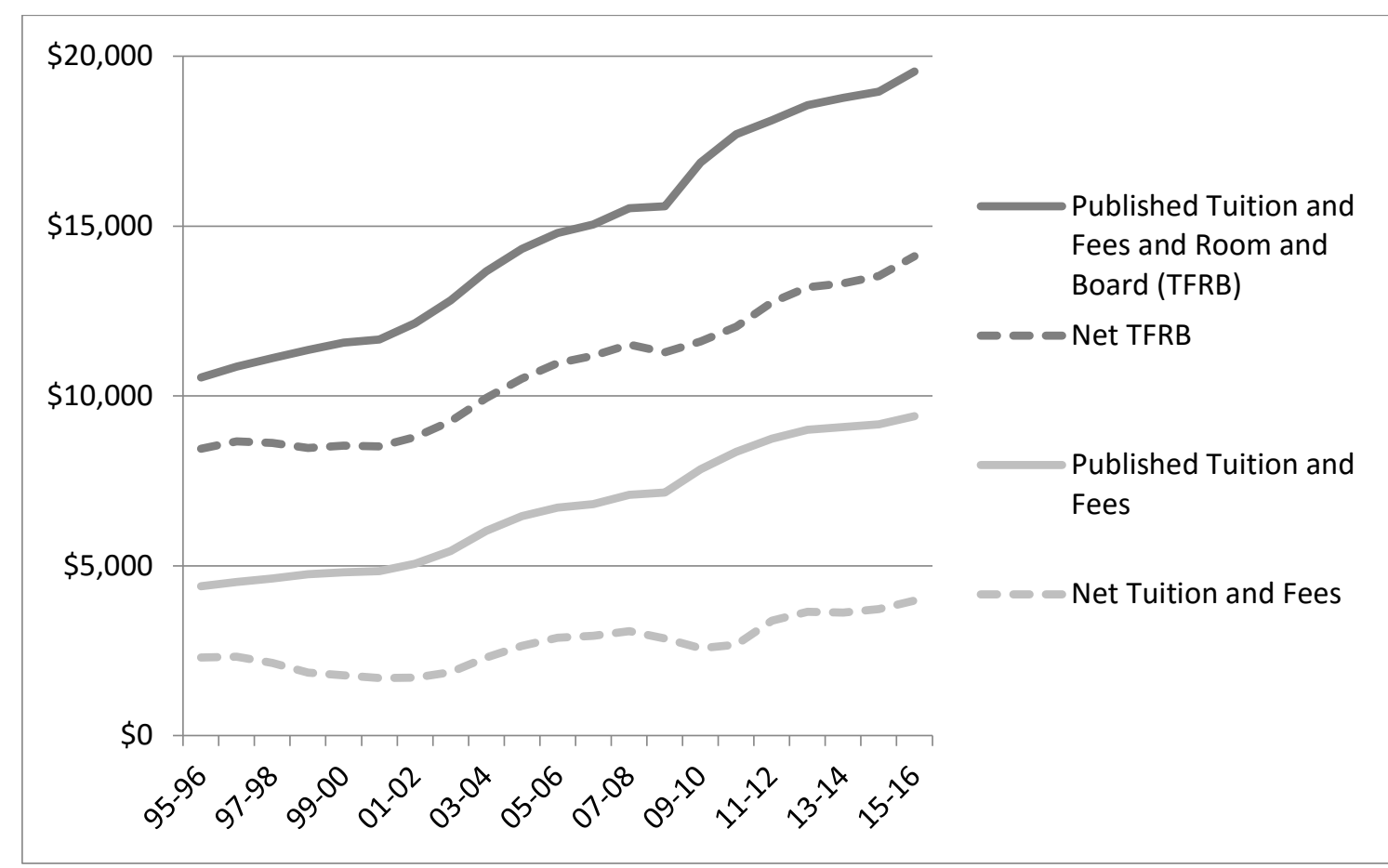

Figure 3. Average published and net prices in 2015 dollars, full-time in-state undergraduate students at public four-year institutions, 1995-96 to 2015-16. Source: College Board Trends in College Pricing 2015 (p. 23, Figure 12).

Data suggest that student financial aid has not kept pace with tuition and fee increases. While the average net tuition and fees paid at in-state institutions was about \$3,980 in 2015 after all applied grant aid and tax credits (College Board, 2015a), cost remains high and thus a formidable barrier for many students. That is especially the case for students from lower-income families, who pay an average net cost of $84 \%$ of their family income in order to enroll in four-year schools (Calahan \& Perna, 2015). ${ }^{4}$ Most students do not pay for the full cost of college-about two-thirds of full-time students enrolled in US higher education receive some form of grant aid to help them finance their education. Still, as noted earlier, traditional major sources of need-based aid such as the Pell Grant have declined steadily in purchasing power. As a result, the proportion of students relying on student loans within the public four-year sector has increased from about 54\% in 1999-00 to 60\% in 2013-14, with the average cumulative loan debt per borrower rising from $\$ 20,800$ to $\$ 25,500$ during the same 15-year period (College Board, 2015b). Collectively, shifts in state funding and increases in cost have transferred the responsibility for college financing toward students, with significant implications for lower-income students and their families, as well as middle-income students who may be on the margins of qualifying for aid, enrolling in college, and persisting until graduation (see Alon, 2011; Heller, 2013; Lovenheim \& Reynolds, 2011; McPherson \& Schapiro, 1998).

\footnotetext{
${ }^{4}$ It is notable that much of the enrollment growth in public institutions is among lower-income students so, in effect, the financially neediest are those who are increasingly covering the escalating costs of higher education (Taylor \& Morphew, 2015).
} 
Strikingly, many institutions have purposively sought autonomy to increase tuition and fee revenue sans governmental oversight or approval. A number of states have granted increasing autonomy to public colleges and universities, offering latitude in decision-making in exchange for less direct state financial support. For example, the Commonwealth of Virginia passed in 2005 the Restructured Higher Education Financial and Administrative Operations Act, which allowed colleges and universities to apply for a particular tier of operational control in purchasing, personnel, construction, technology implementation, and tuition-setting authority (Leslie \& Berdahl, 2008). The law seemed to favor the elite and more research-focused institutions in the state - the University of Virginia, Virginia Tech, and the College of William Mary - as it provided for the increasing of institutional autonomy based on financial and managerial capacity. While those schools willingly accepted a decline in state appropriations for a type of "charter" status akin to that of cities and towns, they nevertheless also agreed to new, tightened reporting procedures to the state to demonstrate performance on 12 state goals (Pusser, 2008).

In the Virginia example, as in other, recent cases of decentralization (e.g., Woodhouse, 2016b), researchers and analysts note a paradox of declining governmental funding coupled with heightened accountability for whatever funds are received. In this way, public colleges and universities could set higher tuition and fee rates to make up for decreased state funding; however, they must demonstrate outcomes that serve the public good. As Zumeta and Kinne (2011) note of such developments, longgone are times when states left lump-sums of money at higher education's doorstep with few questions asked.

Amid broad accountability movements in the private and non-profit sectors, public colleges and universities have indeed been of increasing focus. One particular way of assessing higher education's outcomes and effectiveness has emerged via performance budgeting reforms. Not all states have sought to tie appropriations to institutional outcomes (e.g., completion, retention, graduation rates, etc.), though those that do typically pursue one of three types of policies. Burke and Associates (2005) identify them as performance funding, performance budgeting, and performance reporting. Performance funding carries the sharpest "teeth," tying institutional budgets to outcomes, while performance budgeting uses outcomes as one factor in budgeting decisions, and performance reporting, which provides updates on institutional benchmarks, does not have direct consequences for allocations.

States that adopt performance-funding policies typically have Republican governors and predominantly Republican legislatures, as that U.S. political party tends to have a strong interest in explicitly linking funding and performance in the public sector (McLendon, Hearn, \& Deaton, 2006). Over time, some states have dropped their rather aggressive moves to tie funding to institutional outcomes. The short life-span of some of these policies appears to be associated with a lack of private sector/industry presence in the state, failure to include tertiary education leaders in the policy-making process, and economic downturns (Dougherty, Natow, \& Vega, 2012). In states that have maintained performance-based budgeting mechanisms, outcomes do not suggest powerful effects. Tandberg and Hillman (2014) found that from 1990 to 2010 performance funding had small, marginal but statistically significant effects on baccalaureate completions by about a decade after implementation of the policy. Revised forms of performance funding, now usually termed outcome-based funding, are emerging currently in several U.S. states (McLendon \& Hearn, 2013). Given the nascent nature of these new performance-based approaches, it is important to note that it may take a lengthy period of time to begin to see results as institutions adapt their own internal policies and practices to changed state contexts. 
The combination of state retrenchment of funding and heightened pressure for accountability may have uneven effects on public institutions and sectors. Colleges and universities that still rely on their shares of state appropriations may face continued barriers to pursuing innovative directions as they compete for students, faculty, and other sources of funding. As Brewer and Tierney (2011, p. 23) explain of California:

Over a decade ago, then-Chancellor Barry Munitz invited the California State University (CSU) campuses to become a charter university where they would have increased autonomy and reduced regulation; not a single administration or faculty group wanted to move away from what was then perceived as the security of state funding and operation. Indeed, when California decided to expand its campuses for the UC and the CSU systems, the institutional leaders and faculties chose to create institutions that were far more similar than different from what currently existed. The newest public institutions in California-for example, CSU Channel Islands and UC Merced-offer traditional programs in traditional formats...[and in faculty workloads, faculty composition, and teaching and learning formats are] equivalent to what one finds on every other campus.

Indeed, mid-tier institutions such as those referred to in the California example may also become increasingly susceptible to pressures to emulate others in the field of higher education (Morphew \& Eckel, 2009). In Illinois, the current failure to pass a state budget seems to have heightened the stratification among institutions, with those serving the highest proportion of financially neediest students the most likely to experience the sharpest repercussions. While the public flagship University of Illinois at Urbana-Champaign has depth in resources to buffer for a time from a state budget crisis, other teaching-intensive institutions, which rely on state grant-aid to support rather high proportions of low-income students that they enroll, do not. As one system leader explained, there is fear that these lesser-resourced institutions may encounter "dismantling of our universities piece by piece, as people get laid off and things get shut down. Over time you turn around and you wonder what happened to your university. Piece by piece it just disappeared on you" (Woodhouse, 2016a, p. 2).

\section{Implications of the U.S. Trends}

While students doubtlessly must bear a greater burden of the increasing cost of tuition for their postsecondary study, institutions have also been forced to act in more strategic and entrepreneurial ways. Among these reforms are four core developments, entailing:

- pursuit of revenue and prestige by shaping student enrollments;

- demonstration of the success of graduates in the labor market;

- diversification of revenue streams; and

- expansion of the lower-cost part-time and non-tenured faculty workforce while also competing for high-quality tenure-track faculty

Given the expansion of privatization and accountability in U.S. public higher education, we now turn to a discussion of how these trends, particularly in federal and state policy choices, have affected individuals and institutions in the sector. 


\section{Emergence of Strategic Enrollment Management}

Many public institutions have sought to adapt their admissions processes and engage in strategic enrollment management as a response to declining federal and state funding. In a seemingly pervasive quest to raise both institutional tuition revenues and prestige, these universities have begun to shift institutional student aid away from financially needy students, toward non-need based financial aid and "shaping a class" in deliberate, targeted ways (Baum \& Lapovsky, 2006; Breneman, Doti, \& Lapovsky, 2001; Hearn, 2013). Consequently, institutional aid has increasingly become a strategic enrollment management tool, as public universities mimic their private counterparts and target their so-called "merit aid" toward students with higher incomes or stronger academic credentials. However, names can be deceiving, as "merit aid isn't always going to the very best students," observes Don Hossler, now professor emeritus of educational leadership and policy studies at Indiana University. "It's an intentional strategy to help offset the loss of state support" (Wang, 2013, para. 32, emphasis added).

Strategic enrollment management ("SEM") has traditionally focused on four objectives: (1) defining and marketing institutional goals, (2) including campus stakeholders in the strategic planning process, (3) incorporating strategic financial aid policies and decision making, and (4) restructuring and budgeting in order to enable organizational success (Dixon, 1995). In the present discussion, we focus primarily on the employment of targeted financial aid and marketing strategies in order to meet institutional goals-notably, increased institutional revenue and prestige. Along with the growth of targeted aid, the practice of tuition discounting has emerged. Broadly defined, tuition discounting refers to any form of revenue given up by an institution when they accept less than full price from an enrolling student, while still attempting to maximize overall tuition revenue and meet enrollment management goals (Allan, 1999; Davis, 2003). Thus, colleges and universities charge different prices to different groups of students for the same education, such as the practices of charging greater tuition to out-of-state students or providing need-based grants to lower-income students (Baum \& Lapovsky, 2006). However, in recent decades, this practice has transformed into "financial aid leveraging" or "preferential packaging," whereby institutions grant greater merit aid to higher-income or higher-achieving students, who provide greater net tuition revenues and can help the institution meet academic, financial, and diversity goals (Baum \& Lapovsky, 2006; Hearn \& Warshaw, 2015; Wang, 2013). This trend is also evident at the state level, where an increasing amount of state aid is directed to students without regard for their financial need. While only $10 \%$ of state grant aid was awarded for non-need based aid in 1993-94, this proportion rose to $24 \%$ by 2013-14, and in 15 states, less than half of state financial aid was need-based (College Board, 2015b).

One prominent yet growing example of tuition discounting is charging higher tuition and fees for out-of-state students, who pay an average of 2.5 times the cost of in-state students (College Board, 2015a). While the recruitment of nonresident students may bring greater revenue to public universities, it raises critical questions regarding access and choice for in-state residents, as well as whether such policies are consistent with institutional mission (Baum \& Lapovsky, 2006). Historically, many states have put restrictions upon nonresident enrollment; however, there is evidence that some public universities are looking to change this norm, increasing the share of out-of-state students on campuses (Hearn \& Warshaw, 2015). Wisconsin's legislators recently removed limitations on nonresident enrollment on the state's flagship campus at Madison and the institution's chancellor, Rebecca Blank, is championing increased non-need based aid for both in-state and out-of-state students in order to compete with other public flagships for top-tier students (Woodhouse, 2015). The financial appeal of these students is quite compelling, as UW-Madison's nonresident students pay $\$ 29,7000$ for tuition - nearly three times that of in-state students (Woodhouse, 2015). 


\section{Increasing Stratification in Student Enrollments and Outcomes}

There is much evidence to suggest that the aforementioned trends-increased tuition and fees and the emergence of specific strategic enrollment management practices-have stratified student enrollments in US higher education. In particular, these developments seem to have influenced lowerincome students to attend lower quality institutions with fewer academic and social support services available to help them succeed. While high school graduation rates have nearly equalized across income and racial groups, significant inequality remains in postsecondary affordability, enrollment, persistence, and completion (see Alon, 2011; Bailey \& Dynarski, 2011; Belley \& Lochner, 2007; Hearn, 2013). And as student access to tertiary education has increased, the representation of lower-income students at higher quality four-year institutions has declined (see Bailey \& Dynarski, 2011; Bastedo \& Jaquette, 2011; Hearn, 2013; McPherson \& Schapiro, 1998, Posselt, Jaquette, Bielby, \& Bastedo, 2012).

Instead, researchers are noting that lower- and middle-income students, regardless of academic ability, are more likely to enroll in less-prestigious and lower-resourced four-year regional universities, two-year community colleges, and for-profit universities, and are more likely to have part-time or interrupted enrollment patterns (Bastedo \& Jaquette, 2011; Calahan \& Perna, 2015; Hearn, 2013; Marcus \& Hacker, 2015). In 2012, 55\% of Pell grant recipients (typically with incomes less than $\$ 40,000$ per year) attended a four-year school, while $75 \%$ of their higher income counterparts attended four-year institutions (Calahan \& Perna, 2015). While public flagship universities have increased their low-income enrollment since the mid-1990s, to an average of $28 \%$, they remain concentrated at less prestigious institutions, representing $41 \%$ of students at regional public universities and $42 \%$ at community colleges (Marcus \& Hacker, 2015; Rosinger \& Hearn, 2015). While estimates vary greatly, there are also gaps in graduation rates between the lowest- and highest-income groups range from $26 \%$ within six years of graduation (Alon, 2011) to $40 \%$ within eight years (Heller, 2013). In this way, the opportunity crisis for high-school graduates may entail being unable to attend institutions for which they are qualified, at enrollment levels they want, at the times they want, and ultimately, to graduate (Hearn, 2013).

\section{Shifting Support for Academic Majors and Fields}

Despite longstanding support for student exploration in major choice in the US, several politicians have suggested the need for greater support of STEM and vocationally-focused degrees with potentially greater financial payoffs, at the expense of liberal arts fields. The most dramatic proposals have come from governors in Florida, North Carolina, Texas, and Wisconsin, who have argued for shifting funding toward higher-demand majors, charging higher tuition and fees for students in "non-strategic majors," and creating lower-cost bachelor's degrees in higher-demand fields (see Alvarez, 2012; Anderson, 2011; Flaherty, 2012; Kiley, 2012, 2013). Such proposals represent a growing emphasis on vocational training, lower tuition costs, and performance-based funding metrics among numerous U.S. state leaders.

Though research suggests that students who have studied the humanities and other liberal arts fields have strong critical thinking and reasoning skills, are adaptive and innovative, are likely to attain graduate degrees, and have comparable long-term earnings as professional and preprofessional majors (American Academy of Arts and Sciences, 2013; Arum \& Roksa, 2011; Humphreys, 2014; Humphreys \& Kelly, 2014), such evidence seems largely ignored among some policy-makers. After announcing his intention to draft legislation basing higher-education funding on postgraduate employment outcomes rather than enrollment, North Carolina's Republican Governor Patrick McCrory stated publicly, "If you want to take gender studies that's fine, go to a private school and take it, but I don't want to subsidize that if that's not going to get someone a job" (Kiley, 2013, para. 4). Echoing this sentiment, Florida's Republican governor, Rick Scott, has suggested that students in non-STEM and lower-demand majors should pay higher tuition for their education, despite higher costs to educate students in STEM fields (Alvarez, 2012; Flaherty, 2012). He believes that such a differential tuition policy will create incentives for students to major in strategic fields and deliver much-needed graduates to fill the state's workforce needs. Finally, Republican governors in 
both Florida and Texas have pushed for the creation of several $\$ 10,000$ bachelor's degrees in their states, in order to help keep costs to students and families low while promoting efficiency, accountability, and degree production in high-demand majors (Kiley, 2012).

\section{Diversifying Revenues via New Initiatives and Organizational Restructuring}

Addressing the financial challenges facing his institution, E. Gordon Gee, president emeritus of The Ohio State University, wrote, "We must ask how we sustain ourselves, how we fund excellence, how we invest in new ideas and new partnerships, and how we extend our reach even further to those in need" (Gee, 2011, para. 5). Indeed, to position their universities for greater revenue generation, public higher-education leaders have had to become more creative in developing new initiatives, strategic alliances, and structural forms. Such efforts can impose challenges to traditional notions of institutional mission and the public good.

Hearn and Warshaw (2015) categorize such revenue generation efforts into four broad categories: educational initiatives, research efforts, strategic marketing and branding campaigns, and investment and fundraising strategies. A prominent example of growth in educational initiatives is the rise of online degree programs and partnerships, which can provide institutions with significant profit margins to subsidize their physical campuses and traditional degree programs. Starbucks recently announced a partnership with Arizona State University (ASU), through which the corporation will finance employee enrollment in ASU's online degree programs (Blumenstyk, 2014). Similar efforts have emerged at the University of Florida, where the institution partnered with Pearson to create an online degree program targeting out-of-state enrollment; however, just two years after launching the program, university leaders are seeking to cancel the contract after missing revenue targets by $\$ 170,000$ (Straumsheim, 2015). Institutions are also prioritizing and rewarding faculty research efforts, particularly those in STEM fields, enabling profitable relationships with both government and corporate industry partners. Through this process, universities have also pursued copyrights on faculty research and intellectual property, providing public institutions potential for greater revenue and increased legitimacy (Hearn \& Warshaw, 2015; Slaughter \& Rhoades, 2004). Public institutions have also profited from strategic branding efforts, including marketing campaigns and the pursuit of trademarks. Both provide additional revenue, whether through the use of logos and branding, multimillion dollar contracts with apparel corporations, or increased pursuit of trademarks, providing schools with royalties on the sale of merchandise (e.g., Rooksby, 2014; Slaughter \& Rhoades, 2004). As of 2011-12, collegiate licensing was a massive $\$ 4.6$ billion industry (Rooksby, 2014). Finally, public institutions are continuing to pursue development and fundraising efforts, but at a more intense and feverish pace, mimicking their private school peers as they launch capital campaigns seek donations from alumni and private philanthropists (Cheslock \& Gianneschi, 2008).

Additionally, public colleges and universities have begun to reconsider notions of the traditional academic department, favoring collaboration through institutes, centers, and crossdepartmental ventures that enable interdisciplinarity and valuable partnerships between university and industry. Many view this shift as a manifestation of the newly redesigned American university, via the emergence of a comprehensive "knowledge enterprise" (Crow \& Dabars, 2015, p. 179) linking the public university to the economy and private marketplace (Slaughter \& Rhoades, 2004). In this way, strategic initiatives coincide with fundamental shifts in organizational structure to help institutions position for success in pursuits of broadening revenues (Warshaw, 2015). 


\section{Growing Salary Gaps between Public and Private Universities}

As state subsidies continue to decline and cost-cutting and efficiency are highlighted, public institutions have been less able to maintain the faculty salaries of their private counterparts. Corresponding with the growth in research revenues, a market for top faculty has emerged, providing greater fiscal rewards for top researchers (Slaughter \& Rhoades, 2004). Unfortunately, there is growing evidence of an "academic brain drain" as quality faculty have begun to leave public universities in favor of the higher salaries, benefits, research support, and other benefits offered by top private institutions (Alexander, 2001, p. 114). In an early analysis of these shifting salary trends, Alexander (2001) stated, "Public universities appear to be losing the evolutionary battle of the survival of the fittest" (p. 119); there is little evidence, however, that these gaps have lessened in recent years.

While the salaries of faculty at public and private institutions remained relatively close in the 1970s, a recession in the late 1970s and early 1980s caused states to reduce appropriations to higher education and forced public universities to respond by raising tuition and cutting costs. Faculty salaries represent the largest single item in university budgets; thus, they became a target for spending cuts. In a pattern echoing the growing gaps in per-student expenditures between private and public schools at the time, the relative salary gaps between private and public university faculty began to balloon, leaving most public institutions unable to compete with private universities in the battle for high-quality faculty. From 1979-1980 to 1997-98, the average salary differential between public and private Research I institutions grew from $\$ 1,300$ to $\$ 21,700$ for full professors and from $\$ 900$ to $\$ 8,000$ for associate professors, in 1998 constant dollars (Alexander, 2001).

The market for high-quality faculty has only grown more competitive over time, nationally and internationally, with public universities falling behind at all academic ranks. Recent estimates suggest that faculty salaries at all public four-year colleges average about $92 \%$ of those in the four-year private sector, continuing the downward trend (College Board, 2015a). More critically, not only student-body qualifications but also institutional prestige in public universities may suffer in today's competitive market, to the extent schools are judged by the quality and reputation of their faculty. That is, as public institutions lose battles to hire and retain the most talented faculty, their relative standing in the competition for students, research funding and, ultimately, stature my suffer.

\section{Changing Faculty Composition}

Faculty tenure has long been considered a mainstay of employment in the tertiary education sector in the US, but as emphasis on cost-cutting, performance metrics, and strategic enrollments has risen, tenure itself has been subjected to increased scrutiny. In efforts to cope with these demands, institutions within all sectors of higher education have attempted to enhance institutional efficiency, adaptability, cost savings, and market nimbleness by hiring a greater proportion of part-time lecturers, full-time non-tenure line faculty members, and graduate students as instructors. As reliance on lower-paid and transient members of the faculty workforce grows, many observers fear negative implications for student learning, faculty stratification, and the "unbundling" of the traditional faculty roles of teaching, research, and service (Belkin \& Korn, 2015; Hearn \& Milan, 2013; Hearn \& Warshaw, 2015; Toutkoushian \& Bellas, 2003). 
Despite such concerns, the growth of the contingent faculty workforce has been consistent and undeniable-and perhaps a necessity, given real-dollar declines in state support and the marketdriven nature of the higher education enterprise. While the hiring of non-tenured faculty has been most notable in the for-profit sector (see Figure 4, below), the representation of full-time faculty at four-year institutions has declined from 76\% to 67\% from 1993-94 to 2013-14 (College Board, 2015a). As of 2005 , tenured faculty represented only about $35 \%$ of instructional staff at public institutions, not accounting for graduate student instructors, and contingent faculty members teach nearly half of all courses at public universities (Lee, 2008). What is more, part-time and full-time non-tenured faculty members earn substantially less than their full-time and tenured counterparts (Curtis \& Jacobe, 2006; Toutkoushian \& Bellas, 2003). While estimates vary, data suggest that full-time non-tenure track faculty earn about $26 \%$ less than their tenured counterparts (Curtis \& Jacobe, 2006) and in 2003-04, part-time faculty earned, on average, only $\$ 2,758$ per class taught (Lee, 2008, p. i). As a result, these faculty members often teach a large number of courses and may work for multiple institutions during a single academic term. At many universities, contingent faculty have looked to unionization as a potential solution for poor working conditions, uncertainty of short-term contracts, and inadequacy of pay (Belkin \& Korn, 2015).

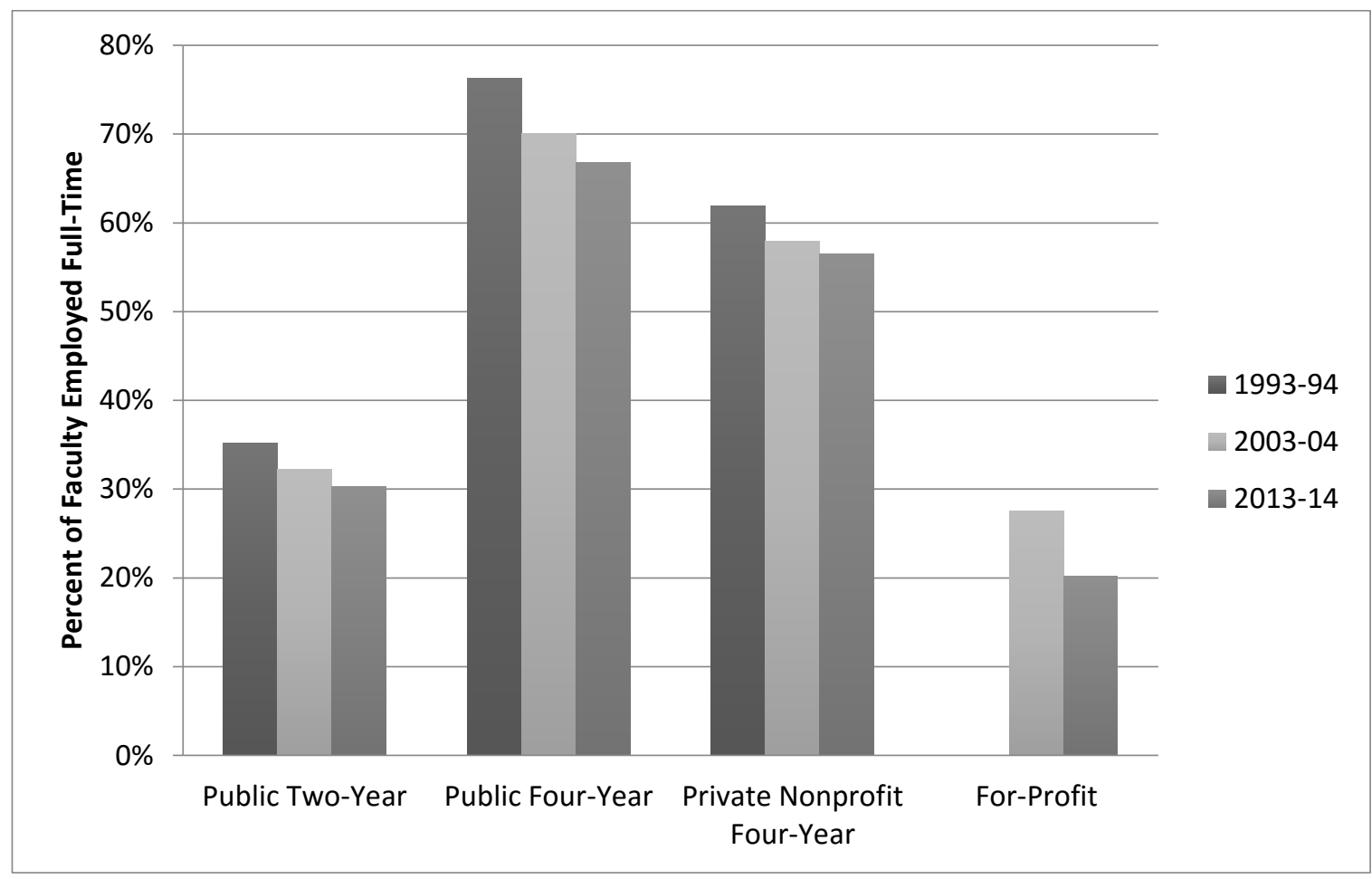

Figure 4. Percentage of faculty in degree-granting postsecondary institutions employed full-time, 1993-94 to 2013-14, selected years. Source: College Board Trends in College Pricing 2015 (p. 40, Figure 30B). 


\section{Conclusions}

The notion of higher education in the service of national and supranational needs is centuries old. The very founding of the first universities in Europe and Asia was linked to the needs of nations and religious bodies for the preservation and transmission of knowledge. While the idea of institutions serving the broader public good is not new, the implementation of that notion inevitably has evolved over time. In American higher education, the founding of Harvard College in the seventeenth century was tied to a new colony's need to produce civic leaders and clergy in North America for North American needs. The federal government's Morrill Land Grant Act in the 1860s created institutions throughout the country devoted to serving the people broadly, rather than serving elites narrowly. Thenceforth, institutions were to be rewarded not only for providing education in applied fields such as business and engineering, but also for serving as practical knowledge bases as technology and industry advanced rapidly in their home states.

As the nation's supply of public institutions grew, their charters increasingly reflected their aim to serve the public good. Knowledgeable democratic citizens were to be the prime products of the nation's universities. Those ideals were amplified as the research mission was incorporated into institutional missions and greater emphasis placed on producing knowledge applicable both to the immediate needs and longer-term development. In later years, the public good was further interpreted to encompass the provision of equal educational opportunity for women and all racial/ethnic and socioeconomic groups. Thus, over time the definition of the broader public good to be served by higher education expanded.

While the public good rose throughout the twentieth century, at least in rhetorical priority, measuring the attainment of some of its aspects remained difficult. What, exactly, is a good citizen? What knowledge is essential to the nation, and thus to all graduates? What good is served by the humanities or social sciences? That difficulty was compounded by the increasing differentiation, atomization, and stratification of institutions and fields in the U.S. As economic challenges and globalization have risen over the last two decades, it comes as little surprise that the "luxury" of funding the less measurably efficient and effective aspects of higher education is under question.

As a result, it is clear that the terms of the debate around the purposes of higher education are shifting. Rizvi (2006) suggests that the precepts of privatization provide the basis for a new managerialist approach to public administration that redefines the relationship between the state and its institutions, and individuals and civil society. Some national interests are surely being served by the movement toward greater privatization and accountability, but these tend to be economic interests relating to growth, employability, and innovation rather than interests relating to development of democratic participation, educational access and equity, and contributing to openness and creativity in society, culture, and knowledge development (Rizvi, 2006; Petras \& Vetmeyer, 2001). Ideally, governments can maintain their commitment to the value of "a lighter hand" in institutional governance while also tailoring selective incentives and disincentives in the service of perhaps less measurable but unquestionably valuable outcomes.

Still, the privatization and accountability movements may be contributing to disequilibrium in U.S. tertiary education. Developments over the past decade in the state of Virginia suggest that highly resourced, elite public institutions may have the financial and managerial capacity to leverage additional autonomy from their states toward creative, entrepreneurially grounded improvement (Pusser, 2008). Mid-tier public universities, however, may not be as well positioned for autonomy, and thus may prefer less risky paths. For example, California's less selective state universities have chosen to remain tied to state funding and have become rather homogenous in structure, operations, and offerings (Brewer \& Tierney, 2011). Of course, among private institutions, and especially among private schools at the margins of status and resources, markets have always driven schools to adopt organizational innovations to help them compete (Kraatz \& Zajac, 1996). But among public institutions, it seems that the uncertainty of resource-flows from the external environment may 
increasingly steer them toward emulative rather than creative behaviors (Morphew \& Eckel, 2009). This hesitancy constrains differentiation in the marketplace. In the end, innovations may be centering in private institutions and in elite public institutions, leaving non-elite public colleges and universities disadvantaged, in stasis and struggling to maintain their quality and resources.

Privatization and accountability trends may also be contributing to disequilibrium in student and faculty flows and status. The U.S. is experiencing deepening stratification in students' institutional destinations, with lower-income students declining in proportional enrollment at elite public and private institutions, and with those same students facing increasing loan debt enrolling in other institutions with growing gaps between tuition and available student aid awards (Hearn, 2013; Taylor \& Morphew, 2015). Among faculty, differences in pay and working conditions are growing between the public and private sectors, especially at the research university level, thus exacerbating stratification.

The sociologist Burton Clark argued that the U.S.'s high reliance on markets to steer higher education has historically tended to produce admirable outcomes (Clark, 1983). Over time, the country's growing allegiance to that approach could correct for the disequilibria noted above. If not, however, more aggressive governmental steering may be needed. In the U.S. at present, the level of national and state involvement required to bring the system into effective balance remains elusive.

Worldwide, privatization and accountability initiatives continue to diffuse, spreading with little evidence of retreat. A number of countries with highly developed systems of tertiary education have shifted some of the costs of education to students and families, typically in the form of tuition fees, eroding longstanding practices and policy-orientations in this arena (Johnstone \& Marcucci, 2010). Since the 1980s, the Australian government has allowed universities to charge tuition fees to international students, which has prompted striking enrollment growth, generated new institutional revenues that reached about $\$ 4$ billion in 2004, and transformed the campus cultures of these institutions (Rizvi, 2006). In the United Kingdom, recently introduced "top-up" fees can reach $€ 4,000$ per year-a striking difference from other EU members whose fees, if they have them, typically range from $€ 200$ to $€ 600$ (Salerno, 2009). ${ }^{5}$ Elsewhere, countries including Australia, China, Japan, \& South Africa have expanded the use of subsidized student loans to enable students overcome financial barriers associated with increases in tuition fees (Johnstone, 2009; Johnstone \& Marcucci, 2010).

France, analogous to the US, has aimed to enhance the global competitiveness of select universities in nanomedical research, but in working toward this goal has triggered new governance arrangements in which elite faculty members - rather than academic deans and chairs-may work directly with policy-makers and institutional leaders on strategy, organizational change, and resource allocations (Louvel, 2016). In nations with aggressively developing tertiary education systems, such as China, Brazil, India, and Mexico, the influence to emulate global trends may be strong, especially when ambitions of achieving "world-class" status for universities drives these efforts (e.g., Altbach \& Balán, 2007; Rhoads et al., 2014; Morphew \& Eckel, 2009).

\footnotetext{
${ }^{5}$ Salerno (2009) notes additional examples of privatization in European public universities: for example, Germany and Estonia have sought to finance institutions based on performance criteria and multiyear performance contracts respectively. In the EU more generally, institutions in Sweden and Scotland have sought to increase revenues from private philanthropy, and others have strengthened their efforts in applied research to attract funding from industry.
} 
As with the U.S., it remains unclear whether these varied accountability and privatization initiatives are meeting their objectives of efficiency and effectiveness. As the trends continue, however, policymakers and institutional leaders may benefit from an increasing array of "experimental evidence" on the movement. Notably, there are growing examples of resistance or, as Rizvi describes it, processes that are "articulated and refracted through the local specificities of the nation-state" (2006, p. 72). Scandinavian countries, for example, have thus far resisted trends toward charging tuition to domestic or international students. In an era of globalization, when the spread and infusion of "neoliberal" mindsets and the steady retrenchment in public funding of social institutions seems increasingly irreversible, which nations and universities will resist these trends and pursue their own distinctive paths? 


\section{References}

Alexander, F. K. (2001). The silent crisis: The relative fiscal capacity of public universities to compete for faculty. Review of Higher Education, 24(2), 113-129.

Allan, R. G. (1999). Taxonomy of tuition discounting. Journal of Student Financial Aid, 29(2), 7-20.

Alon, S. (2011). Who benefits most from financial aid? The heterogeneous effect of need-based grants on students' college persistence. Social Science Quarterly, 92(3), 807-829.

Altbach, P. G., \& Balán, J. (Eds.). (2007). World class worldwide: Transforming research universities in Asia and Latin America. Baltimore: Johns Hopkins University Press.

Alvarez, L. (2012, December 9). Florida may reduce tuition for select majors. The New York Times. Retrieved from http://www.nytimes.com/2012/12/10/education/florida-may-reduce-tuition-forselect-majors.html

American Academy of Arts and Sciences (2013). The heart of the matter: The humanities and social sciences for a vibrant, competitive, and secure nation. Cambridge, MA: Author.

Anderson, Z. (2011, October 10). Rick Scott wants to shift university funding away from some degrees. Herald Tribune. Retrieved from http://politics.heraldtribune.com/2011/10/10/rick-scott-wants-toshift-university-funding-away-from-some-majors/

Arum, R., \& Roksa, J. (2011). Academically adrift: Limited learning on college campuses. Chicago: University of Chicago Press.

Bailey, M. J., \& Dynarski, S. M. (2011). Gains and gaps: Changing inequality in US college entry and completion. NBER Working Paper No. 17633. Retrieved from http://www.nber.org/papers/w17633

Bastedo, M.N. (2005). The making of an activist governing board. Review of Higher Education, 28(4), 551-570.

Bastedo, M. N., \& Jaquette, O. (2011). Running in place: Low-income students and the dynamics of higher education stratification. Educational Evaluation and Policy Analysis, 33(3), 318-339.

Baum, S., \& Lapovsky, L. (2006). Tuition discounting: Not just a private college practice. The College Board. New York, NY.

Belkin, D., \& Korn, M. (2015). Colleges' use of adjuncts come under pressure. The Wall Street Journal. Retrieved from http://www.wsj.com/articles/collegesuseofadjunctinstructorscomesunderpressure1424118108

Belley, P., \& Lochner, L. (2007). The changing role of family income and ability in determining educational achievement. National Bureau of Economic Research: Working Paper 13527. Retrieved from http://www.nber.org/papers/w13527

Ben-David, J. (1992). Centers of learning: Britain, France, Germany, United States (2nd ed.). New Brunswick, NJ: Transaction Publishers.

Berdahl, R.O. (1998). Balancing self interest and accountability: St Mary's College of Maryland. In T.J. MacTaggart (Ed.), Seeking excellence through independence: Liberating colleges and universities from excessive regulation (pp. 59-83). San Francisco: Jossey-Bass.

Blumenstyk, G. (2014, June 27). Starbucks plan shines a light on the profits in higher education. The Chronicle of Higher Education. Retrieved from http://chronicle.com/article/Starbucks-Plan-Shines-aLight/147395/

Bozeman, B. (2007). Public values and public interest: Counterbalancing economic individualism. Washington, DC: Georgetown University Press.

Breneman, D. W., Doti, J. L., \& Lapovsky, L. (2001). Financing private colleges and universities: The role of tuition discounting. In M. B. Paulsen, \& J. C. Smart (Eds.), The finance of higher education: Theory, research, policy, and practice (pp. 461-479). New York: Agathon Press.

Brewer, D. J., \& Tierney, W. G. (2011). Barriers to innovation in U.S. higher education. In B. Wildavsky, A.P. Kelly, \& K. Carey (Eds.), Reinventing higher education: The promise of innovation (pp. 11-40). 
Cambridge: Harvard University Press.

Burke, J. C., \& Associates. (Eds.). (2005). Achieving accountability in higher education. San Francisco: Jossey-Bass.

Calahan, M., \& Perna, L. (2015). Indicators of higher education equity in the United States: 45 year trend report. Washington, DC: The Pell Institute. Retrieved from http://www.pellinstitute.org/publicationsIndicators_of_Higher_Education_Equity_in_the_United_States_45_Year_Report.shtml

Cheslock, J. J., \& Gianneschi, M. (2008). Replacing state appropriations with alternative revenue sources: The case of voluntary support. Journal of Higher Education, 79(2), 208-229.

Clark, B. R. (1983). The higher education system: Academic organization in cross-national perspective. Berkeley, CA: University of California Press.

Clark, B. R. (1998). Creating entrepreneurial universities: Organizational pathways of transformation. Oxford: Pergamon Press.

College Board, The. (2015a). Trends in college pricing: 2015. Washington, DC: Author. Retrieved from http://trends.collegeboard.org/sites/default/files/trends-college-pricing-web-final-508-2.pdf

College Board, The. (2015b). Trends in student aid: 2015. Washington, DC: Author. Retrieved from http://trends.collegeboard.org/sites/default/files/trends-student-aid-web-final-508-2.pdf

Crow, M. M., \& Dabars, W. B. (2015). Designing the new American university. Baltimore: Johns Hopkins University Press.

Curtis, J. W., \& Jacobe, M. F. (2006). AAUP contingent faculty index 2006. Washington, DC: American Association of University Professors. Retrieved from http://www.aaup.org/sites/default/files/files/AAUPContingentFacultyIndex2006.pdf

Dadayan, L., \& Boyd, D. J. (2013, February). State tax revenues continue slow rebound: At the end of fiscal 2012, personal income tax revenues were still below the peak levels recorded in fiscal 2008. Report published by The Nelson A. Rockefeller Institute of Government, University at Albany, NY. Retrieved from http://www.rockinst.org/pdf/government_finance/state_revenue_report/SSR90.pdf

Davis, J. S. (2003). Unintended consequences of tuition discounting. New Agenda Series. Indianapolis, IN: Lumina Foundation for Education.

Department of Education. (2013). Department launches college affordability and outreach initiative today-starting with student advocates. Retrieved from http://blog.ed.gov/2013/09/departmentlaunches-college-affordability-and-value-outreach-initiative-today-starting-with-studentadvocates/

Desrochers, D. M., \& Hurlburt, S. (2016). Trends in college spending: 2003-2013. Washington, DC: The Delta Cost Project. Retrieved from http://www.deltacostproject.org/sites/default/files/products/154626\%20Final01\%20Delta\%20Cost\%20Project\%20College\%20Spending\%2011131.406.P0.02.001\%2 $0 \ldots . . p d f$

Dill, D. (1997). Higher education markets and public policy. Higher Education Policy, 10, 167-185.

Dixon, R. R. (Ed.). (1995). Making enrollment management work. San Francisco: Jossey-Bass.

Dougherty, K. J., Natow, R. S., \& Vega, B. E. (2012). Popular but unstable: Explaining why state performance funding systems in the United States often do not persist. Teachers College Record, $114,1-41$.

Duderstadt, J. J. (2000). A University for the $21^{\text {st }}$ Century. Ann Arbor: University of Michigan Press.

Flaherty, C. (2012, November 26). U. of Florida history professors fight differential tuition. Inside Higher Ed. Retrieved from https://www.insidehighered.com/news/2012/11/26/u-florida-historyprofessors-fight-differential-tuition 
Gee, E. G. (2011). Colleges must find innovative ways to finance their missions. The Chronicle of Higher Education. Retrieved from http://chronicle.com/article/Colleges-Must-Find-Innovative/129568/

Geiger, R. L. (2004). Knowledge and money: Research universities and the paradox of the marketplace. Stanford, CA: Stanford University Press.

Grove, J. (2015, September 14). Social sciences and humanities faculties to close in Japan after ministerial decree. Times Higher Education. Retrieved from https://www.timeshighereducation.com/news/social-sciences-and-humanities-faculties-closejapan-after-ministerial-decree

Harvey, D. (2005). A brief history of neoliberalism. Oxford: Oxford University Press.

Hauptman, A. M. (2012). Increasing higher education attainment in the U.S.: Challenges and opportunities. In A. P. Kelly, \& M. Schneider (Eds.), Getting to graduation: The completion agenda in higher education (pp. 17-47). Baltimore: Johns Hopkins University Press.

Hearn, J. C. (2013). Commotion at the gates: Higher education's evolving role in U.S. inequality. In J. R. Thelin (Ed.), The rising costs of higher education (pp. 163-173). Santa Barbara, CA: ABC-CLIO.

Hearn, J., \& Milan, M. C. (2013). Here today, gone tomorrow? The increasingly contingent faculty workforce. TIAA-CREF Institute: Advancing Higher Education. Retrieved from https://www.tiaacrefinstitute.org/public/pdf/institute/research/advancing_higher_education/ahe_ contingentfaculty0313.pdf

Hearn, J. C., \& Warshaw, J.B. (2015, April). The evolving organizational character of the public research university. Paper presented at the Institutional Design Futures Conference, Scottsdale, AZ.

Heller, D. E. (2013). The role of finances in postsecondary access and success. In L. W. Perna, \& A. P. Jones (Eds.), The state of college access and completion: Improving college success for students from underrepresented groups (pp. 96-114). New York: Routledge.

Hovey, H. A. (1999). State spending for higher education in the next decade: The battle to sustain current support. San Jose, CA: National Center for Public Policy and Higher Education. Retrieved from http://www.highereducation.org/reports/hovey/hovey.shtml

Humphreys, D. (2014). Employment outcomes in the four-year sector: The value of liberal arts degrees. Change, 46(3), 64-66.

Humphreys, D., \& Kelly, P. J. (2014). How liberal arts and sciences majors fare in employment: A report on earnings and long-term career paths. Washington, DC: American Association of Colleges and Universities.

Johnstone, D. B. (2009). Worldwide trends in financing higher education: A conceptual framework. In J. Knight (Ed.), Financing access and equity in higher education (Vol. 17, pp. 1-18). Rotterdam, Netherlands: Sense Publishers.

Johnstone, B. \& Marcucci, P. N. (2010). Financing higher education worldwide: Who pays? Who should pay? Baltimore: Johns Hopkins University Press.

Kiley, K. (2012, November 30). Texas, Florida, and Wisconsin governors see large overlap in higher education platforms. Inside Higher $E d$. Retrieved from https://www.insidehighered.com/news/2012/11/30/texas-florida-and-wisconsin-governors-seelarge-overlap-higher-education-platforms

Kiley, K. (2013, January 30). North Carolina governor joins chorus of republicans critical of liberal arts. Inside Higher Ed. Retrieved from https://www.insidehighered.com/news/2013/01/30/northcarolina-governor-joins-chorus-republicans-critical-liberal-arts

Kraatz, M. S., \& Zajac, E. J. (1996). Exploring the limits of the new institutionalism: The causes and consequences of illegitimate organizational change. American Sociological Review, 61, 812-836.

Lederman, D. (2010, December 1). No grades for states this year. Inside Higher Ed. Retrieved from https://www.insidehighered.com/news/2010/12/01/measuring_up 
Lee, J. (2008). Reversing course: The troubled state of academic staffing and a path forward: American Federation of Teachers, Washington, DC.

Leslie, D. W., \& Berdahl, R. O. (2008). The politics of restructuring higher education in Virginia: A case study. Review of Higher Education, 31(3), 309-328.

Louvel, S. (2016). Going interdisciplinary in French and US universities: Organizational change and university policies. Research in the Sociology of Organizations, 46, 329-359.

Lovenheim, M. F., \& Reynolds, C. L. (2011). Changes in postsecondary choices by ability and income: Evidence from the national longitudinal surveys of youth. Journal of Human Capital, 5(1), 70-109.

Marcus, J., \& Hacker, H. K. (2015, December 17). The rich-poor divide on America's college campuses is getting wider, fast. The Hechinger Report. Retrieved from http://hechingerreport.org/thesocioeconomic-divide-on-americas-college-campuses-is-getting-wider-fast

Marginson, S. (2000). Rethinking academic work in the global era. Journal of Higher Education Policy and Management, 22(1), 23-35.

Marginson, S. (2012). The "public" contribution of universities in an increasingly global world. In B. Pusser, K. Kempner, A. Marginson, \& I. Ondorika (Eds.), Universities and the public sphere: Knowledge creation and state building in the era of globalization (pp. 7-25). New York: Routledge.

McGuinness, Jr., A.C. (2011). The states and higher education. In P.G. Altbach, P.J Gumport, \& R.O Berdahl (Eds.), American higher education in the 21 ${ }^{\text {st }}$ Century: Social, political, and economic challenges (3rd ed.) (pp. 139-169). Baltimore: Johns Hopkins University Press.

McLendon, M. K., \& Hearn, J. C. (2009). Viewing recent US governance reform whole: "Decentralization" in a distinctive context. In J. Huisman (Ed.), Perspectives on the governance of higher education: Alternative frameworks for coordination (pp. 161-181). New York: Routledge.

McLendon, M. K., \& Hearn, J. C. (2013). The resurgent interest in performance-based funding for higher education. Academe. 99(6), 25-30.

McLendon, M. K., Hearn, J. C., \& Deaton, R. (2006). Called to account: Analyzing the origins and spread of state performance-accountability policies for higher education. Educational Evaluation and Policy Analysis, 28(1), 1-24.

McPherson, M. S., \& Schapiro, M. O. (1998). The student aid game: Meeting need and rewarding talent in American higher education. Princeton, NJ: Princeton University Press.

Mettler, S. (2011). The submerged state: How invisible government policies undermine American democracy. Chicago: University of Chicago Press.

Morphew, C. C., \& Eckel, P. D. (Eds.). (2009). Privatizing the public university: Perspectives from across the academy. Baltimore: Johns Hopkins University Press.

Perna, L. W., \& Finney, J. E. (2014). The attainment agenda: State policy leadership in higher education. Baltimore: Johns Hopkins University Press.

Petras, J., \& Vetmeyer, H. (2001). Globalization unmasked. London: Zed Books.

Posselt, J. R., Jaquette, O., Bielby, R., \& Bastedo, M. N. (2012). Access without equity: Longitudinal analyses of institutional stratification by race and ethnicity, 1972-2004. American Educational Research Journal, 49(6), 1074-1111.

Pusser, B. (2008). The state, the market and the institutional estate: Revisiting contemporary authority relations in higher education. In J.C. Smart (Ed.), Higher education: Handbook of theory and research (Vol. 23). Dordrecht, Netherlands: Springer.

Rhoads, R. A., Wang, X., Shi, X., \& Chang, Y. (2014). China's rising research universities: A new era of global ambition. Baltimore: Johns Hopkins University Press.

Rizvi, F. (2006). The ideology of privatization in higher education: A global perspective. In D.M. Priest, \& E. P. St. John (Eds.), Privatization and public universities (pp. 65-86). Bloomington, IN: Indiana University Press. 
Rooksby, J. H. (2014). University ${ }^{\mathrm{TM}}$ : Trademark rights accretion in higher education. Harvard Journal of Law and Technology, 27(2), 350-418.

Rosinger, K. O., \& Hearn, J. C. (2015, November). Driver of upward mobility or capitalism's greatest friend? Examining connections between higher education enrollments and broader social and economic stratification. Paper presented at the annual meeting of the Association for the Study of Higher Education, Denver.

Salerno, C. (2009). Privatizing the public European university. In C.C. Morphew \& P.D. Eckel (Eds.), Privatizing the public university: Perspectives from across the academy (pp. 160-180). Baltimore: Johns Hopkins University Press.

Schugurensky, D. (1999). Higher education restructuring in the era of globalization: Toward a heteronomous model? In R. Arnove, \& C. Torres (Eds.), Comparative education: The dialectic of the global and the local (pp. 283-304). Lanham, MD: Rowman and Littlefield.

Slaughter, S., \& Rhoades, G. (1996). The emergence of a competitiveness research and development policy coalition and the commercialization of academic science and technology. Science, Technology, and Human Values, 21(3), 303-339.

Slaughter, S., \& Rhoades, G. (2004). Academic capitalism and the new economy: Markets, state, and higher education. Baltimore: Johns Hopkins University Press.

Stephan, P. (2012). How economics shapes science. Cambridge: Harvard University Press.

St. John, E., \& Wooden, O. S. (2006). Privatization and federal funding for higher education. In D.M. Priest, \& E. P. St. John (Eds.), Privatization and public universities (pp. 38-64). Bloomington: Indiana University Press.

Straumsheim, C. (2015, October 23). Less than two years after launch, U. of Florida reboots online education initiative. Inside Higher $E d$. Retrieved from https://www.insidehighered.com/news/2015/10/23/less-two-years-after-launch-u-florida-rebootsonline-education-initiative

Tandberg, D. A., \& Hillman, N. W. (2014). State higher education performance funding: Data, outcomes, and policy implications. Journal of Education Finance, 39(3), 222-242.

Taylor, B. J., \& Morphew, C. C. (2015). Trends in cost-sharing in the US and potential international implications. Higher Education Policy, 28, 129-149.

Toutkoushian, R. K., \& Bellas, M. L. (2003). The effects of part-time employment and gender on faculty earnings and satisfaction: Evidence from the NSOPF:93. Journal of Higher Education, 74(2), 172-195.

Volkwein, J. F., \& Tandberg, D. A. (2008). Measuring up: Examining the connections among state structural characteristics, regulatory practices, and performance. Research in Higher Education, 49(2), 180-197.

Wang, M. (2013, September 11). The quest by public colleges for revenue and prestige squeezes needy students. The Chronicle of Higher Education. Retrieved from http://chronicle.com/article/PublicColleges-Quest for/141541/

Warshaw, J. B. (2015, November). STEM-centered organizational innovations in the research university: Structure, science, and money. Paper presented at the annual meeting of the Association for the Study of Higher Education, Denver, CO.

Winston, G. (1999). Subsidies, hierarchy and peers: The awkward economics of higher education. Journal of Economic Perspectives, 13(1), 13-36.

Woodhouse, K. (2015, December 18). Playing the aid game. Inside Higher Ed. Retrieved from https://www.insidehighered.com/news/2015/12/18/university-wisconsin-ups-its-merit-aid-effortbetter-compete-peers

Woodhouse, K. (2016a, January 7). Universities left footing the bill as budget crisis looms in Illinois. Inside Higher Ed. Retrieved from https://www.insidehighered.com/news/2016/01/07/universitiesleft-footing-bill-budget-crisis-looms-illinois 
Woodhouse, K. (2016b, January 14). Mixed reviews for plan to change Tennessee higher education governance. Inside Higher Ed. Retrieved from

https://www.insidehighered.com/news/2016/01/14/mixed-reviews-plan-change-tennessee-highereducation-governance

Zumeta, W. (2010). The great recession: Implications for higher education. In The NEA Almanac of Higher Education (pp. 29-42). Washington, DC: National Education Association. Retrieved from http://www.nea.org/assets/img/PubAlmanac/Zumeta_2010.pdf

Zumeta, W., \& Kinne, A. (2011). Accountability policies: New and old. In D.E. Heller (Ed.), The states and public higher education policy: Affordability, access, and accountability (2nd ed., pp. 173-199). Baltimore: Johns Hopkins University Press. 